\title{
Touch Prep Slide
}

National Cancer Institute

\section{Source}

National Cancer Institute. Touch Prep Slide. NCI Thesaurus. Code C84518.

A glass slide with attached tissue prepared by direct touching of the tissue to the slide. 